\title{
Abnormal Regulation of Renal Kallikrein in Experimental Diabetes Effects of Insulin on Prokallikrein Synthesis and Activation
}

Ayad A. Jaffa, Donald H. Miller, Graham S. Bailey, Julie Chao, Harry S. Margolius, and Ronald K. Mayfield

Departments of Medicine and Pharmacology, Medical University of South Carolina, Charleston, South Carolina 29425; and Veterans Administration Medical Center, Charleston, South Carolina 29425

\begin{abstract}
The effects of streptozotocin (STZ) diabetes and insulin on regulation of renal kallikrein were studied in the rat. 1 and 2 wk after STZ injection, diabetic rats had reduced renal levels and urinary excretion of active kallikrein. Tissue and urinary prokallikrein levels were unchanged, but the rate of renal prokallikrein synthesis relative to total protein synthesis was reduced $30-45 \%$ in diabetic rats. Treatment of diabetic rats with insulin prevented or reversed the fall in tissue level and excretion rate of active kallikrein and normalized prokallikrein synthesis rate. To further examine insulin's effects, nondiabetic rats were treated with escalating insulin doses to produce hyperinsulinemia. In these rats, renal active kallikrein increased. Although renal prokallikrein was not increased significantly by hyperinsulinemia, its synthesis was increased. As this was accompanied by proportionally increased total protein synthesis, relative kallikrein synthesis rate was not changed. Excretion of active kallikrein was unchanged, but prokallikrein excretion was markedly reduced. Therefore, increased tissue active kallikrein seen with hyperinsulinemia can be explained not only by increased synthesis but also by retention and increased activation of renal prokallikrein. These studies show that STZ diabetes produces an impairment in renal kallikrein synthesis and suggest that this disease state also impairs renal prokallikrein activation. The findings also suggest that insulin modulates renal kallikrein production, activation, and excretion.
\end{abstract}

\section{Introduction}

Studies suggest that renal kallikrein and its kinin products have a role in renal hemodynamic regulation $(1,2)$. It was recently demonstrated that kallikrein-containing cells of the rat (3) and human (Vio, C., personal communication) distal nephron are adjacent (within $5 \mu \mathrm{m}$ ) to the glomerular afferent arteriole. Intact glomeruli have been shown to have specific binding sites for kinins (4). These findings and the fact that kinins can stimulate eicosanoid production by both afferent

This work was presented in part at the 45th Annual Meeting of the American Diabetes Association, Baltimore, MD, June 16-18, 1985, at the Southern Regional Meeting of the American Federation for Clinical Research, New Orleans, LA, February 5-8, 1986, and was published in abstract form (1985. Diabetes. 34[Suppl. 1]:11A, and 1986. Clin. Res. 34:196A).

Address correspondence to Dr. Mayfield, Dept. of Medicine, Medical University of South Carolina, 171 Ashley Ave., Charleston, SC 29425.

Received for publication 7 January 1987 and in revised form 25 June 1987.

J. Clin. Invest.

(C) The American Society for Clinical Investigation, Inc.

$0021-9738 / 87 / 12 / 1651 / 09 \$ 2.00$

Volume 80, December 1987, 1651-1659 arterioles and glomerular mesangial cells support the possibility that the renal kallikrein-kinin system may be a participant in the tubuloglomerular feedback mechanisms that regulate glomerular function (5-8). Kinins can also cause marked changes in electrolyte and water transport in renal tubules and in other transporting epithelia (9-12). These properties of renal kallikrein and kinins may be relevant to numerous observations, made over the years, of abnormalities of both the enzyme and its products in hypertensive and renal diseases (13).

Because diabetes mellitus is associated with abnormalities of renal hemodynamics and renal electrolyte metabolism, which may contribute to the complications of the disease, we began studies of renal kallikrein in diabetic humans and animal models $(14,15)$. We previously found that renal levels and excretion of immunoreactive kallikrein and kallikrein-like esterase activity are reduced in streptozotocin (STZ) ${ }^{1}$ diabetes, and this reduction precedes the onset of systemic hypertension in this model (15). Hayashi et al. (16) reported similar findings. In the present studies, we have investigated mechanisms responsible for the reduced renal kallikrein content and enzymatic activity in this diabetic model as well as the effects of insulin on renal kallikrein synthesis, levels, and excretion. A monoclonal antibody that recognizes only active kallikrein was used to quantitate active and prokallikrein in renal tissue and urine (17), and a recently developed technique was used to measure the rate of prokallikrein synthesis (18).

\section{Methods}

STZ-diabetic rats. Male Sprague-Dawley rats (Charles River Breeding Laboratories, Inc., Wilmington, MA) weighing $185-220 \mathrm{~g}$ were used in these studies. Rats were housed four to five per cage, except when urine was collected over $24 \mathrm{~h}$, when they were housed individually in metabolic cages (Nalge Co., Rochester, NY). At all times rats had free access to water and regular chow. Diabetes was induced by a single intravenous injection of STZ, $65 \mathrm{mg} / \mathrm{kg}$ body wt. STZ was a gift from the Upjohn Co., Kalamazoo, MI. Control rats received no injection. After $24 \mathrm{~h}$ diabetes was confirmed in STZ-treated rats by tail-vein plasma glucose level. Rats were excluded if their plasma glucose was $<250$ $\mathrm{mg} / \mathrm{dl}$. Glucose levels were subsequently measured at 9 a.m., at intervals throughout the studies, to characterize the diabetic state. Diabetic rats treated with insulin were given daily (10 a.m.) subcutaneous injections of 2.00-2.25 $\mathrm{U}$ protamine zinc insulin (PZI; protamine zinc and iletin, Eli Lilly \& Co., Indianapolis, IN). Insulin treatment was begun $24 \mathrm{~h}$ after STZ injection, after diabetes was confirmed, or delayed for $1 \mathrm{wk}$. In the latter studies PZI was supplemented on the first 2 d of treatment with $2 \mathrm{U}$ of regular insulin (Iletin II, Eli Lilly \& Co.) given at 5 p.m.

Urines collected were assayed for glucose and active and prokallikrein. At predetermined times, rats were anesthetized with sodium

1. Abbreviations used in this paper: PZI, protamine zinc insulin; SBTI, soybean trypsin inhibitor; STZ, streptozotocin. 
pentobarbital ( $50 \mathrm{mg} / \mathrm{kg}$ body wt i.p.) or ether (synthesis rate studies), and kidneys were removed for measurements of total protein, kallikrein, and kallikrein synthesis rate. Each kidney was perfused via the renal hilus with $10 \mathrm{ml}$ iced cold saline $(0.9 \%)$ and then immediately frozen at $-20^{\circ} \mathrm{C}$ until assays were performed. To measure synthesis rates, rats were injected intraperitoneally with $\left[{ }^{35} \mathrm{~S}\right]$ methionine: $1 \mu \mathrm{Ci} / \mathrm{g}$ body wt, diluted $1 \mu \mathrm{Ci} / \mu$ l saline (translation grade, $>800 \mathrm{Ci} / \mathrm{mmol}$, New England Nuclear, Boston, MA). 20 min after injection, rats were anesthetized and the kidneys prepared as above.

Hyperinsulinemic nondiabetic rats. Renal kallikrein synthesis, level, and excretion rate were measured in normal rats treated with insulin to produce hyperinsulinemia. The protocol used is shown in Fig. 1 and was adapted from Kobayashi and Olefsky (19). Male Sprague-Dawley rats weighing 180-230 g were injected subcutaneously, twice daily (from day 2), with progressively increasing doses of isophane insulin suspension (neutral protamine Hagedorn, Iletin II, Eli Lilly \& Co.). One-third of the daily dose was given at 9 a.m., and two-thirds at 5 p.m. The control group was injected at the same times with an equal volume of insulin diluting fluid (Eli Lilly \& Co.). To avert hypoglycemia, insulin-treated rats had free access to sugar cubes and $5 \%$ glucose drinking water, in addition to regular rat chow. Rats were housed four to five per cage or individually in metabolic cages for urine collection. On days 5 and 12, tail-vein plasma glucose levels were measured before the a.m. and p.m. doses of insulin. On day 13, $24 \mathrm{~h}$ after the last injection, the rats were anesthetized and kidneys were removed and prepared as above. Insulin levels were measured in plasma obtained at the end of the study by cardiac puncture. Animals in which kallikrein synthesis rate was measured received an intraperitoneal injection of $\left[{ }^{35} \mathrm{~S}\right]$ methionine $20 \mathrm{~min}$ before being anesthetized and killed.

Preparation of kidney homogenates. Kidney tissue was minced and homogenized in $5 \mathrm{ml}$ PBS $\left(0.14 \mathrm{M} \mathrm{NaCl}\right.$ in $0.01 \mathrm{M} \mathrm{Na}_{2} \mathrm{HPO}_{4}-$ $\mathrm{NaH}_{2} \mathrm{PO}_{4}, \mathrm{pH} 7.4$ ) with a teflon/glass homogenizer (15 strokes). Sodium deoxycholate was then added to the tissue homogenate $(0.5 \%$, final concentration) which was then incubated at $4^{\circ} \mathrm{C}$ for $60 \mathrm{~min}$. The homogenate was centrifuged $(27,000 \mathrm{~g})$ at $4^{\circ} \mathrm{C}$ for $45 \mathrm{~min}$ and the supernatant centrifugally filtered through Sephadex G-25 (Pharmacia Fine Chemicals, Piscataway, NJ) to remove salts and detergent (15). Filtered supernatant was used for the kallikrein and protein assays and measurements of kallikrein synthesis.

Assay of kallikreins. Active kallikrein was measured in urine and kidney tissue by a radioimmunoassay (20), which was modified by using a monoclonal antibody (hybridoma clone $\mathrm{V}_{1} \mathrm{C}_{3}$ ) that recognizes only active tissue kallikrein (17). Prokallikrein was measured after its conversion to active enzyme by trypsin. Time of incubation, ratios of trypsin to homogenate protein concentration, and trypsin to soybean trypsin inhibitor (SBTI) were evaluated to determine conditions for maximum activation of prokallikrein and complete trypsin inhibition by SBTI. Aliquots of urine $(10 \mu \mathrm{l})$ were incubated with trypsin $(1 \mu \mathrm{g}$, type III from bovine pancreas; Sigma Chemical Co., St. Louis, MO) in

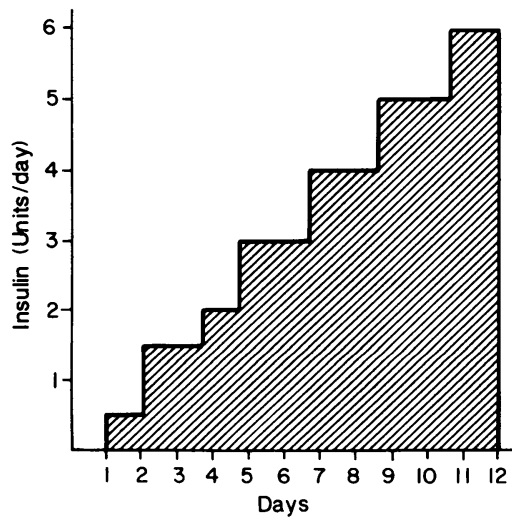

Figure 1. Protocol for producing hyperinsulinemia in nondiabetic rats. Insulin (neutral protamine Hagedorn) was given twice daily, with one-third of the daily dose given at 9 a.m. and two-thirds at 5 p.m. Rats were given access to sugar cubes and $5 \%$ glucose drinking water to avert hypoglycemia.
$40 \mu 10.2 \mathrm{M}$ Tris- $\mathrm{HCl}$ buffer, $\mathrm{pH} 8.0$, for $15 \mathrm{~min}$ at $37^{\circ} \mathrm{C}$. Trypsin was then inhibited with SBTI (8 $\mu \mathrm{g}$, type I; Sigma Chemical Co.), and incubation was continued an additional $15 \mathrm{~min}$. For activation of prokallikrein in tissue homogenate $(10 \mu \mathrm{l})$, the concentrations of trypsin and SBTI were doubled, and the incubation period was $60 \mathrm{~min}$. After activation, the urine incubate was diluted 250-fold and the tissue incubate was diluted 5 -fold in assay buffer (PBS, containing $1 \%$ bovine serum albumin, $\mathrm{pH}$ 7.0) for radioimmunoassay. Measured immunoreactive kallikrein in trypsin-treated samples is total kallikrein. Active kallikrein was measured in aliquots of urine or tissue homogenate that were incubated with premixed trypsin and SBTI, as well as buffer alone. The values obtained for active kallikrein in the latter two tubes were not significantly different (e.g., urine: $160 \pm 9$ vs. $161 \pm 11 \mu \mathrm{g} / \mathrm{d}$, mean $\pm \mathrm{SE}, n=12$, trypsin/SBTI vs. buffer alone, respectively). The prokallikrein level was calculated by subtracting active from total kallikrein. In experiments in which kallikrein synthesis was measured, renal kallikrein content was also measured by a radioimmunoassay that incorporates the same polyclonal antiserum used for kallikrein precipitation in the synthesis rate measurement (18). Since this antiserum does not distinguish active from prokallikrein, the measured levels reflect total tissue kallikrein (20). Tissue kallikrein levels are expressed as nanograms per milligram protein.

Tissue kallikrein synthesis rate. Relative kallikrein synthesis rate was measured using $\left[{ }^{35} \mathrm{~S}\right]$ methionine, according to the technique of Miller et al. (18). To measure incorporation of the labeled amino acid into total protein, duplicate aliquots $(20 \mu \mathrm{l})$ of desalted homogenate supernatant were treated with $50 \mu \mathrm{l}$ of $0.1 \mathrm{M} \mathrm{NaOH}$ at $37^{\circ} \mathrm{C}$ for 30 min. Bovine serum albumin and casein hydrolysate were then added to each aliquot ( 0.1 and $0.2 \%$ final concentrations, respectively). Each tube was treated with $0.5 \mathrm{ml} 10 \% \mathrm{TCA}$, and the precipitated protein was recovered after centrifugation $(4,000 \mathrm{~g})$ at $4^{\circ} \mathrm{C}$ for $10 \mathrm{~min}$. The pellet was washed twice with $1.0 \mathrm{ml} 5 \%$ TCA containing $0.2 \%$ casein hydrolysate. After final centrifugation, the pellet was retained, dissolved in $0.2 \mathrm{ml} 0.1 \mathrm{M} \mathrm{NaOH}$, and transferred to a vial containing liquid scintillation cocktail for counting of radioactivity. Each tube was washed with $0.3 \mathrm{ml}$ of $\mathrm{H}_{2} \mathrm{O}$, and this was also added to the counting vial.

Incorporation of $\left[{ }^{35} \mathrm{~S}\right]$ methionine into kallikrein was measured in the desalted homogenate supernatant by precipitating kallikrein with a sheep anti-rat kallikrein antiserum. Kidney homogenate supernatant was first recentrifuged $(27,000 \mathrm{~g})$ at $4^{\circ} \mathrm{C}$ for $90 \mathrm{~min}$. The pellet was discarded, and to the supernatant were added Triton X-100, SDS, and EDTA ( $1 \%, 0.1 \%$, and $0.1 \mathrm{mM}$ final concentrations, respectively). The supernatant was then centrifuged $(181,000 \mathrm{~g})$ at $4^{\circ} \mathrm{C}$ for $45 \mathrm{~min}$ in an ultracentrifuge with a $50 \mathrm{Ti}$ rotor (Beckman Instruments, Inc., Fullerton, CA.). To the resulting supernatant was added unlabeled carrier kallikrein, to achieve a final kallikrein content of $8 \mu \mathrm{g} /$ tube in a final volume of $0.8-1.0 \mathrm{ml}$. Undiluted kallikrein antiserum $(5 \mu \mathrm{l} / \mu \mathrm{g} \mathrm{kal}-$ likrein) was added to duplicate aliquots $(0.8-1.0 \mathrm{ml})$, and these were incubated for $18 \mathrm{~h}$ at $4^{\circ} \mathrm{C}$. Another set of duplicate tubes was treated with equal amounts of nonimmune sheep serum to measure nonspecific precipitation. After incubation, all tubes were centrifuged $(5,000$ $g$ ) at $4^{\circ} \mathrm{C}$ for $30 \mathrm{~min}$. The precipitates were recovered and washed twice with $1 \mathrm{ml} \mathrm{H}_{2} \mathrm{O}$ containing Triton X-100, SDS, and EDTA (concentrations as above). The final pellet was dissolved in $0.2 \mathrm{ml} 0.1 \mathrm{M} \mathrm{NaOH}$. This dissolved pellet, along with $0.3 \mathrm{ml} \mathrm{H}_{2} \mathrm{O}$ used to rinse each tube, was counted as described for the TCA precipitates. Efficiency of immunoprecipitation was assessed by measuring the precipitation of ${ }^{125}$ I-rat urinary kallikrein added to identically processed tissue samples. This did not differ between diabetic and control tissues and averaged $60 \%$. Therefore, values were not corrected for efficiency of precipitation.

Other assays. Plasma and urine glucose were measured by the glucose-oxidase method (21) in a glucose analyzer (Beckman Instruments, Inc.). Tissue homogenate protein was measured by the method of Lowry et al. (22), using bovine serum albumin as standard. Plasma insulin was measured by radioimmunoassay (23).

Statistical analysis. Data are expressed as mean \pm SE. Differences 
were determined by Student's $t$ test for paired or unpaired observations, by analysis of variance for repeated measures (BMDP2V, BMDP Statistical Software Inc., Los Angeles, CA), or by nonparametric analysis using the Wilcoxon rank-sum test. Differences were considered significant at a level of $P<0.05$.

\section{Results}

Renal kallikrein levels and excretion in diabetes. Renal tissue levels of total, active, and prokallikrein in control and diabetic rats at 2 wk are shown in Fig. 2. A reduction in total kallikrein seen in diabetic rats is entirely accounted for by a reduction in the level of active kallikrein $(25.6 \pm 2.2$ vs. $54.7 \pm 2.7 \mathrm{ng} / \mathrm{mg}$ protein, diabetic vs. control, respectively, $P<0.001)$. Renal prokallikrein levels were unchanged by the diabetic state (24.1 \pm 1.8 vs. $24.7 \pm 3.0 \mathrm{ng} / \mathrm{mg}$ protein, diabetic vs. control). Plasma glucose levels in the diabetic rats, measured at the end of the study, were $489 \pm 22 \mathrm{mg} / \mathrm{dl}$, compared with $119 \pm 3 \mathrm{mg} / \mathrm{dl}$ in control rats $(P<0.001)$. Final body weights were $234 \pm 6 \mathrm{~g}$ in diabetic rats and $288 \pm 2 \mathrm{~g}$ in controls $(P<0.001)$.

We then examined the effects of insulin replacement on both renal levels and urinary excretion of active and prokallikrein. 1 wk after induction of diabetes $(n=13)$, kallikrein excretion was measured in diabetic $(n=12)$ and control rats $(n$ $=12$ ). Six of the rats from each group were killed for measurement of renal kallikrein and the remainder of the diabetic rats $(n=7)$ were begun on daily insulin treatment (2.25 U PZI). At the end of the second week, urinary and renal tissue kallikrein levels were measured in these insulin-treated diabetic and agematched control rats.

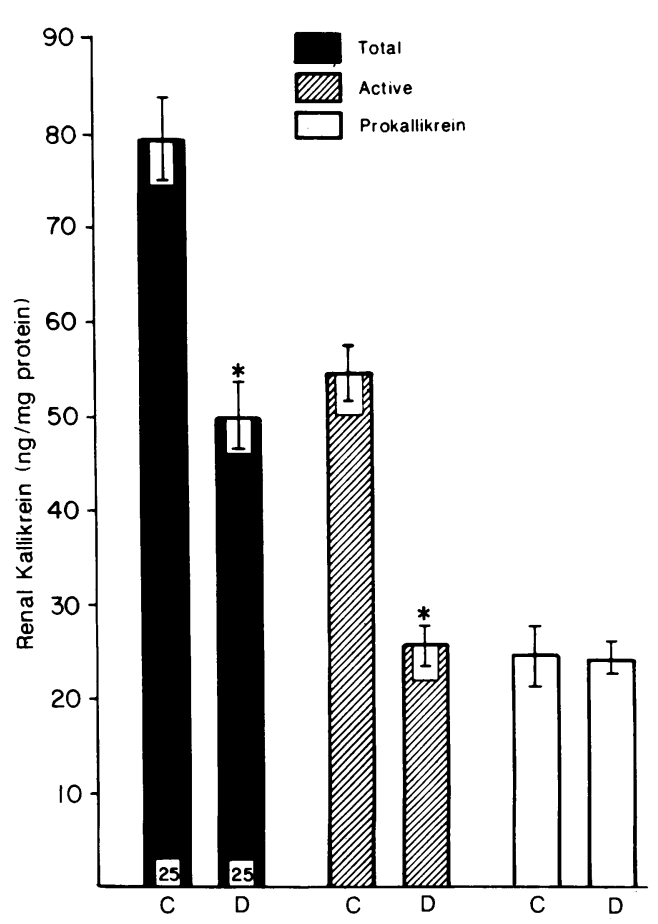

Figure 2. Renal tissue levels of total, active, and prokallikrein in control (C) and 2-wk STZ-diabetic (D) rats. Active kallikrein was measured by radioimmunoassay with a monoclonal antibody specific for active enzyme. Prokallikrein was derived after assay of a trypsin-activated sample. Bars indicate the mean $\pm S E$ and the numbers at the base of the solid bars represent the number of animals in each group for all measurements. $* P<0.001$ compared with control.
The body weights, plasma glucose levels, and urinary glucose excretion of these diabetic and control rats are shown in Table I. Body weight was reduced in diabetic rats after $1 \mathrm{wk}$, but after insulin replacement weight increased, such that diabetic and control rats had similar weights at the end of the second week. Plasma glucose levels in diabetic rats were markedly increased at 1 and $7 \mathrm{~d}$, and were associated with heavy glycosuria on day 7 . Insulin treatment reduced plasma and urinary glucose to or below control levels on day 14 .

Renal levels and urinary excretion of active and prokallikrein in these rats are shown in Fig. 3. After 1 wk, diabetic rats had reduced renal tissue levels of active kallikrein. This reduction in active kallikrein (44\%) was similar to the reduction seen after 2 wk of diabetes in the first study (53\%). Neither renal prokallikrein nor total kallikrein level was changed after 1 wk of diabetes. The reduction in renal active kallikrein induced by diabetes was accompanied by a reduction in excretion of active enzyme, and the normal renal prokallikrein level was accompanied by normal prokallikrein excretion. Replacement of insulin in diabetic rats, for $7 \mathrm{~d}$, returned renal and urinary active kallikrein to levels not different from control rats. The fall in renal kallikrein induced by diabetes, and reversed by insulin, was also evident when kallikrein levels are expressed as nanograms kallikrein per gram tissue or nano-

Table I. Body Weights, and Plasma and Urinary Glucose in Control and Diabetic Rats before (Days 1 and 7) and after (Day 14) Insulin Treatment*

\begin{tabular}{|c|c|c|c|c|}
\hline & \multicolumn{4}{|l|}{ Day } \\
\hline & 0 & 1 & 7 & 14 \\
\hline \multicolumn{5}{|c|}{ Body weight $(g)$} \\
\hline Control & $\begin{array}{l}201 \pm 3.5 \\
(12)\end{array}$ & & $\begin{array}{l}250 \pm 4.8 \\
(12)\end{array}$ & $\begin{array}{l}300 \pm 7.0 \\
(6)\end{array}$ \\
\hline Diabetic & $\begin{array}{l}198 \pm 3.5 \\
(13)\end{array}$ & & $\begin{array}{l}206 \pm 7.1^{\ddagger} \\
(13)\end{array}$ & $\begin{array}{l}289 \pm 5.0 \\
(7)\end{array}$ \\
\hline \multicolumn{5}{|c|}{$\begin{array}{l}\text { Plasma glucose } \\
\qquad(m g / d l)\end{array}$} \\
\hline Control & & $\begin{array}{l}125 \pm 4 \\
(12)\end{array}$ & $\begin{array}{l}165 \pm 6 \\
(12)\end{array}$ & $\begin{array}{l}180 \pm 6 \\
(6)\end{array}$ \\
\hline Diabetic & & $\begin{array}{l}383 \pm 20^{\ddagger} \\
(13)\end{array}$ & $\begin{array}{l}468 \pm 28^{\ddagger} \\
(13)\end{array}$ & $\begin{array}{l}105 \pm 23^{\S} \\
(7)\end{array}$ \\
\hline \multicolumn{5}{|c|}{$\begin{array}{l}\text { Urinary glucose } \\
\qquad(g / d)\end{array}$} \\
\hline Control & & & $\begin{array}{l}0.01 \pm 0.001 \\
(12)\end{array}$ & $\begin{array}{l}0.02 \pm 0.003 \\
(6)\end{array}$ \\
\hline Diabetic & & & $\begin{array}{l}8.69 \pm 0.540^{\ddagger} \\
(12)\end{array}$ & $\begin{array}{l}0.27 \pm 0.160 \\
(6)\end{array}$ \\
\hline
\end{tabular}

* Diabetic rats were injected with STZ on day 0. Rats not killed on day 7 were begun on insulin treatment, which continued through day 14 ( $2 \mathrm{U}$ regular for $2 \mathrm{~d}$ and $2.25 \mathrm{U}$ PZI for $7 \mathrm{~d}$ ). Plasma glucose levels were measured from tail-vein plasma on day 1 and from cardiac puncture under anesthesia on days 7 and 14, thus accounting for the increase in plasma glucose in control rats between days 1 and 7. Numbers of rats in each group are given in parentheses below each value.

$\ddagger P<0.001$ vs. control.

$\S P<0.02$ vs. control. 


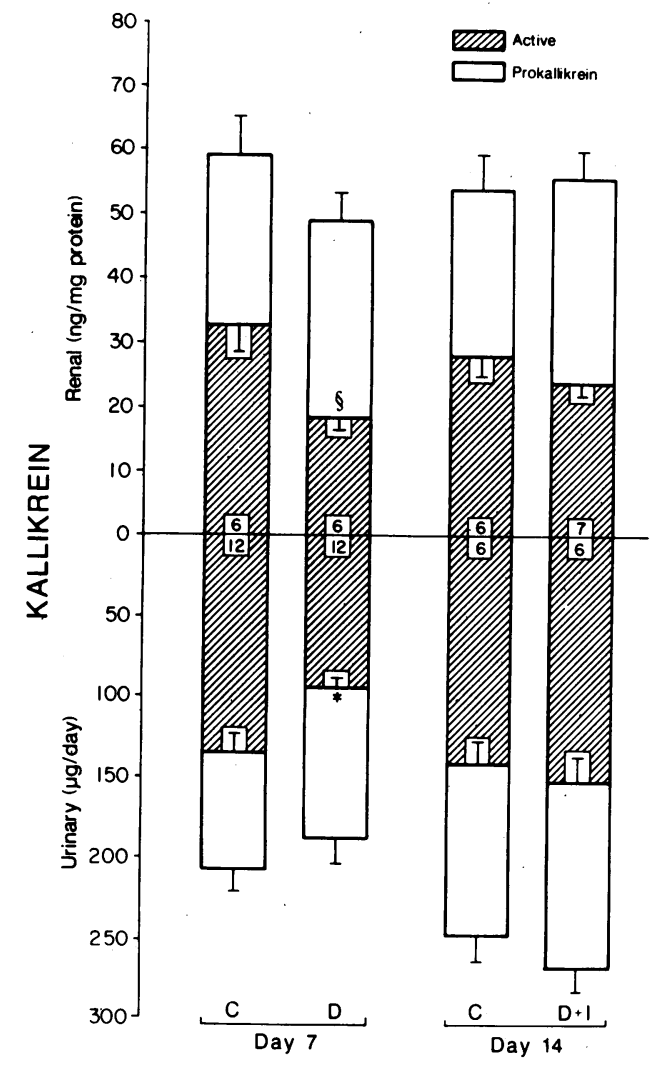

Figure 3. Levels of renal and urinary active and prokallikrein in control (C), STZ-diabetic (D), and STZ-diabetic rats treated with insulin $(D+I)$. After $7 \mathrm{~d}$, six control and six diabetic rats were killed for measurement of renal kallikrein. The remaining diabetic rats were begun on insulin treatment (see Methods for details). After $7 \mathrm{~d}$ of insulin treatment $(D+I)$, these rats and their age-matched controls were killed on day 14. At $7 \mathrm{~d}$, diabetic rats had reduced renal and urinary active kallikrein, and these changes were reversed by insulin replacement. Prokallikrein levels were unchanged. The number at the base of each bar is the number of animals on which the measurements were made. $* P<0.001, \S P<0.05$, compared with control.

grams per kidney, and therefore was not secondary to altered renal size or protein content.

Renal kallikrein synthesis in diabetes. The reductions in active kallikrein in renal tissue and urine, together with the normal prokallikrein level, suggest that activation of the proenzyme may be impaired in diabetes. If activation is impaired, the absence of raised tissue or urinary prokallikrein suggests that prokallikrein synthesis also might be impaired. Therefore, prokallikrein synthesis was measured in two studies. Study 1 examined synthesis in untreated diabetic and control rats, and in study 2 measurements were made in insulintreated diabetic rats (Table II).

In study 1 , diabetic rats showed reduced body weight and marked hyperglycemia 2 wk after STZ, compared with control rats. Renal total kallikrein, measured with polyclonal antiserum, was significantly reduced in diabetic rats, and this reduction was accompanied by a proportional decrease in the relative rate of prokallikrein synthesis (Table II). The level was reduced by $43 \%$ and synthesis by $45 \%$ compared with control. Measurement of renal kallikrein with the monoclonal antibody radioimmunoassay showed a similar, $49 \%$, reduction in total kallikrein. As before, this reduction was due to reduced active kallikrein $(23.6 \pm 3.7$ vs. $63.2 \pm 5.3 \mathrm{ng} / \mathrm{mg}$ protein, diabetic vs. control, respectively, $P<0.001$ ), whereas renal prokallikrein was unchanged $(16.7 \pm 1.4$ vs. $17.6 \pm 2.4 \mathrm{ng} / \mathrm{mg}$ protein).

In study 2, untreated diabetic rats showed reduced weight gain and marked hyperglycemia at $2 \mathrm{wk}$, but the insulintreated rats had body weights and plasma glucose levels not different from controls. The diabetic rats in study 2 showed significantly reduced renal total kallikrein and reduced prokallikrein synthesis; however, insulin-treated diabetic rats showed normal total kallikrein content and normal prokallikrein synthesis rate (Table II). Similar to study 1 , active renal kallikrein (monoclonal assay) in diabetic rats was reduced, compared with levels in control rats $(32.5 \pm 2.6$ vs. $54.5 \pm 3.6$ $\mathrm{ng} / \mathrm{mg}$ protein, $P<0.001)$. Insulin-treated diabetic rats showed normal active kallikrein $(43.8 \pm 3.0 \mathrm{ng} / \mathrm{mg}$ protein). Again, renal prokallikrein was not reduced in diabetic rats $(21.7 \pm 2.1$ vs. $24.1 \pm 1.9 \mathrm{ng} / \mathrm{mg}$ protein, diabetic vs. control, respectively).

Renal kallikrein levels and excretion in hyperinsulinemia. The effects of insulin on renal kallikrein were also studied in nondiabetic rats made hyperinsulinemic by treatment with insulin. The protocol is shown in Fig. 1. Plasma glucose and insulin levels in these insulin-treated and control rats are shown in Table III. In inșulin-treated rats, p.m. plasma glucose levels were significantly reduced by day 5 , yet remained within the normal range. By day 12 , the insulin-treated rats showed a further reduction in p.m. plasma glucose. The plasma insulin level obtained 20-22 h after the last p.m. insulin injection was significantly increased in these rats, compared with control rats.

Renal kallikrein levels (day 13) and urinary excretion (day 12) are shown in Fig. 4. The level of active, as well as total, renal kallikrein was significantly increased in hyperinsulinemic rats compared with controls $(P<0.05$ or less). Renal prokallikrein tended to increase, but the change was not statistically significant $(P<0.07)$. In contrast to increased renal levels of kallikrein, urinary excretion of total and prokallikrein were significantly reduced in hyperinsulinemic rats $(P<0.005$, both), with prokallikrein excretion nearly half that in controls. This finding of reduced total and prokallikrein excretion on day 12 , in the face of increased renal levels of total and active enzyme, is supported by additional measurements obtained in a subset of rats from each group ( $n=6$, each). In these rats excretion rates were measured throughout the 12-d course of insulin treatment. The results (Fig. 5) show a sustained reduction in prokallikrein excretion in hyperinsulinemic rats from day 9. Active kallikrein excretion in these rats did not differ from controls throughout the $12 \mathrm{~d}$ of study.

Renal kallikrein synthesis in hyperinsulinemia. Renal kallikrein synthesis was measured in groups of hyperinsulinemic and control rats. Plasma glucose levels on day 12 (p.m.) in hyperinsulinemic rats in this study were similar $(61 \pm 6 \mathrm{mg} / \mathrm{dl})$ to those reported above. Renal levels and synthesis rates of kallikrein, measured on day 13, are shown in Table IV. The tissue level of total kallikrein (polyclonal antibody radioimmunoassay) was significantly increased in hyperinsulinemic rats. Measurements with the monoclonal antibody radioimmunoassay showed that renal active kallikrein was increased in hyperinsulinemic rats $(74.9 \pm 4.1$ vs. $59.9 \pm 3.7 \mathrm{ng} / \mathrm{mg}$ protein, $P$ $<0.02$ ) without a significant increase in prokallikrein $(45.2 \pm 3.5$ vs. $40.9 \pm 2.6 \mathrm{ng} / \mathrm{mg}$ protein, hyperinsulinemic vs. 
Table II. Renal Kallikrein Content and Synthesis Rate in Control, Diabetic, and Insulin-treated Diabetic

(Diabetes Plus Insulin) Rats at 2 wk

\begin{tabular}{|c|c|c|c|}
\hline & $\begin{array}{l}\text { Control } \\
(n=16)\end{array}$ & $\begin{array}{l}\text { Diabetic } \\
(n=20)\end{array}$ & Diabetes + insulin \\
\hline \multicolumn{4}{|l|}{ Study 1} \\
\hline Body weight $(g)$ & $290 \pm 2$ & $233 \pm 4^{\ddagger}$ & \\
\hline Plasma glucose $(m g / d l)$ & $120 \pm 4$ & $506 \pm 17^{\ddagger}$ & \\
\hline Kallikrein content ( $n g / m g$ protein) & $47.7 \pm 2.4$ & $27.0 \pm 1.6^{\ddagger}$ & \\
\hline Kallikrein synthesis rate:* & $3.04 \pm 0.43$ & $1.68 \pm 0.09^{\S}$ & \\
\hline \multicolumn{4}{|l|}{$10^{3} \times$ ratio $(1) /(2)$} \\
\hline 1 Kallikrein $\mathrm{cpm} / \mathrm{mg}$ protein & $8.83 \pm 1.47$ & $6.69 \pm 0.61$ & \\
\hline \multirow[t]{2}{*}{2 TCA protein $\mathrm{cpm} / \mathrm{mg}$ protein } & $3,711 \pm 564$ & $3,933 \pm 271$ & \\
\hline & $\begin{array}{l}\text { Control } \\
(n=8)\end{array}$ & $\begin{array}{l}\text { Diabetic } \\
(n=6)\end{array}$ & $\begin{array}{l}\text { Diabetes + insulin } \\
(n=15)\end{array}$ \\
\hline \multicolumn{4}{|l|}{ Study 2} \\
\hline Body weight $(g)$ & $303 \pm 5$ & $244 \pm 18^{\ddagger}$ & $293 \pm 5$ \\
\hline Plasma glucose $(m g / d l)$ & $127 \pm 5$ & $440 \pm 18^{\ddagger}$ & $160 \pm 27$ \\
\hline Kallikrein content ( $\mathrm{ng} / \mathrm{mg}$ protein) & $39.3 \pm 2.9$ & $23.7 \pm 2.8^{\S}$ & $43.0 \pm 1.6$ \\
\hline \multicolumn{4}{|l|}{ Kallikrein synthesis rate:* } \\
\hline $10^{3} \times$ ratio $(1) /(2)$ & $1.90 \pm 0.21$ & $1.33 \pm 0.10^{\prime \prime}$ & $1.91 \pm 0.14$ \\
\hline 1 Kallikrein $\mathrm{cpm} / \mathrm{mg}$ protein & $19.77 \pm 7.2$ & $12.05 \pm 3.2^{\| \prime}$ & $18.55 \pm 6.92$ \\
\hline 2 TCA protein $\mathrm{cpm} / \mathrm{mg}$ protein & $11,086 \pm 826$ & $8,894 \pm 423$ & $9,862 \pm 769$ \\
\hline
\end{tabular}

* Rats were injected with ${ }^{35}$ S $]$ methionine (intraperitoneally) and killed after $20 \mathrm{~min}$. The incorporation of methionine label was measured in immunoprecipitated kallikrein (line 1) and total, TCA-precipitated protein (line 2). The ratio of these counts is the relative rate of kallikrein synthesis (see Methods for details). Kallikrein content shown is total immunoreactive kallikrein measured with polyclonal antiserum. See text for active and prokallikrein levels. ${ }^{\ddagger} P<0.001,{ }^{\S} P<0.005, \quad " P<0.05$ or less, vs. control and diabetes plus insulin (study 2 ).

control, respectively). $\left[{ }^{35}\right.$ S $]$ Methionine incorporated into kallikrein and into total protein were both significantly increased in hyperinsulinemic rats (Table IV). Therefore, the relative rate of kallikrein synthesis was not different, suggesting that synthesis of many renal proteins was increased by insulin.

\section{Discussion}

In a previous study we found that renal tissue levels and urinary excretion of total immunoreactive kallikrein were re-

Table III. Plasma Glucose and Insulin Levels in Control and Hyperinsulinemic Rats

\begin{tabular}{|c|c|c|c|c|c|}
\hline & \multicolumn{4}{|c|}{ Plasma glucose $(\mathrm{mg} / \mathrm{dl})$} & \multirow{3}{*}{$\begin{array}{l}\text { Plasma } \\
\text { insulin }\end{array}$} \\
\hline & \multicolumn{2}{|l|}{ Day 5} & \multicolumn{2}{|l|}{ Day 12} & \\
\hline & a.m. & p.m. & a.m. & p.m. & \\
\hline & & & & & $\mu U / m l$ \\
\hline $\begin{array}{l}\text { Control } \\
\qquad(n=10)\end{array}$ & - & $127 \pm 4$ & - & $124 \pm 2$ & $41.4 \pm 4.0$ \\
\hline $\begin{array}{l}\text { Hyperinsulinemic } \\
\quad(n=14)\end{array}$ & $130 \pm 3$ & $102 \pm 8^{\ddagger}$ & $145 \pm 4$ & $70 \pm 12^{*}$ & $69.0 \pm 8.8^{\ddagger}$ \\
\hline
\end{tabular}

The protocol of twice daily insulin treatment to produce hyperinsulinemia in rats is shown in Fig. 1. Control rats were injected with equal volumes of vehicle. Plasma for glucose was drawn before insulin injections at 9 a.m. and 5 p.m. Plasma for insulin was drawn $22 \mathrm{~h}$ after the final p.m. insulin dose.

* $P<0.001$ vs. control.

$\ddagger P<0.01$ vs. control. duced in the STZ-diabetic rat (15). The application of a newly developed, monoclonal antibody radioimmunoassay for active kallikrein (17) now reveals that STZ diabetes reduces renal and urinary active kallikrein, while prokallikrein levels in tissue and urine remain normal. In addition, the relative kallikrein synthesis rate is also reduced in the STZ-diabetic rat, and this is the first disease state in which an abnormality of kallikrein synthesis has been found. This reduction in prokallikrein synthesis, accompanied by a normal tissue prokallikrein level and a reduced level of active kallikrein, suggests that the reduction in active kallikrein in STZ diabetes is due to impaired renal prokallikrein activation, rather than an increase in the level of an inhibitor of active kallikrein. This conclusion is also supported by the finding that kallikrein was reduced in measurements using the kallikrein polyclonal antiserum, which detects complexed kallikrein (24).

The response of renal kallikrein to insulin treatment, in either STZ-diabetic or normal rats, suggests that insulin modulates renal kallikrein production and that changes in circulating insulin levels might explain the renal kallikrein abnormalities in diabefes. First, replacement of insulin in STZ-diabetic rats resulted in a normalization of kallikrein synthesis, tissue level, and excretion rate. Second, in diabetic rats, untreated or treated with insulin, the level of renal active kallikrein correlated directly with the plasma insulin level measured at the same time ( $r=0.66$, data not shown). Third, administration of insulin to normal rats, in a dosage which produced hyperinsulinemia, produced a significant increase in the tissue level of active kallikrein and tended to increase the renal prokallikrein level. Fourth, measurements of synthesis rate in this model of insulin excess revealed that incorporation of methionine label 


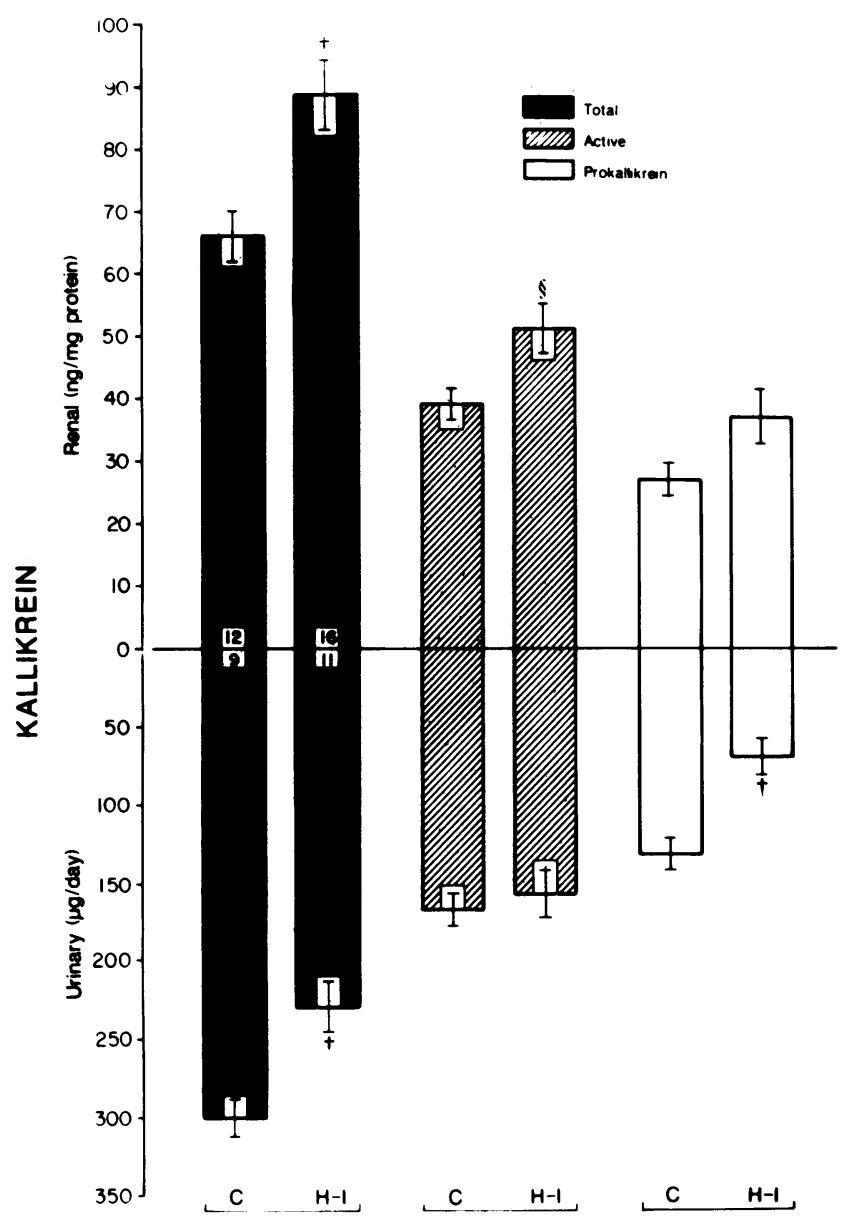

Figure 4. Levels of renal and urinary total, active, and prokallikrein in control (C) and hyperinsulinemic (H-I) nondiabetic rats. After 12 $\mathrm{d}$ of treatment with escalating doses of insulin (Fig. 1), renal active kallikrein was increased in the $\mathrm{H}-\mathrm{I}$ group. Urinary excretion of total and prokallikrein were reduced compared with controls. Each bar represents the mean $\pm \mathrm{SE}$ of measurements made on the number of animals indicated at the base of the solid bars for each group. $\dagger P$ $<0.005, \S P<0.05$, compared with control.

into kallikrein, as well as into TCA-precipitated protein, was increased (Table IV). Since these increases in incorporation of label were proportional, kallikrein synthesis relative to total protein synthesis was not increased by insulin excess.

Taken together, these responses in diabetic and normal rats suggest that insulin's effects on the synthesis of kallikrein and total protein differ between states of low, normal, and excess insulin. That is, incorporation of $\left.{ }^{35} \mathrm{~S}\right]$ methionine into renal kallikrein was increased after insulin replacement in diabetic rats and after insulin administration which produced insulin excess in normal rats. However, incorporation of labeled amino acid into total, TCA-precipitated protein was significantly increased only in the latter. Although we did not detect an increase in TCA-precipitated protein counts in the insulintreated diabetic rats, it is possible that insulin replacement did increase synthesis of some proteins other than kallikrein, but that we were not able to detect the increase in counts that would be contributed from these proteins, as we were able to do for selectively precipitated kallikrein.

It is relevant to point out that phosphoenolpyruvate car-

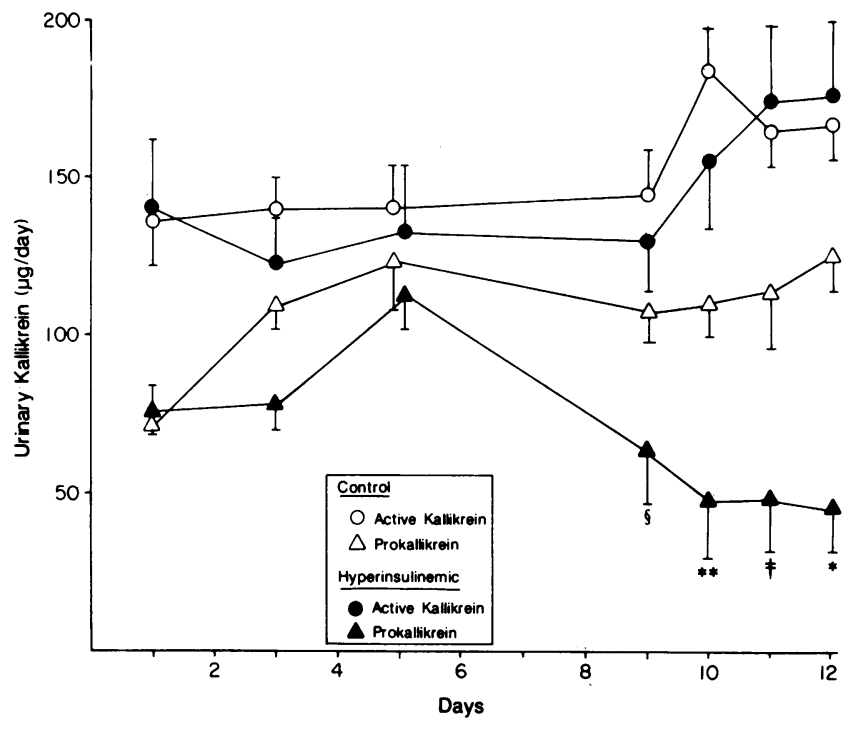

Figure 5. Urinary excretion of active and prokallikrein in control and hyperinsulinemic rats. Treatment with escalating doses of insulin for $12 \mathrm{~d}$ (Fig. 1) resulted in a significant reduction in the excretion of prokallikrein, which was first noted on day $9 . * P<0.001$, $* * P<0.01, \ddagger P<0.02, \S P<0.05$, compared with control.

boxykinase, the only other specific renal protein for which synthesis rate has been measured in diabetes, showed an opposite response from that we observed for tissue kallikrein. The level and synthesis of this enzyme was increased in alloxan-diabetic rats (25). Similarly, Seyer-Hansen found that total renal protein, total RNA, DNA, and renal weight were increased shortly after the induction of STZ diabetes, and insulin treatment prevented increases in protein and RNA, but not DNA (26). It is uncertain whether these changes reflect increased protein synthesis in the diabetic kidney, as studies of amino acid incorporation were not done. In studies of other renal hypertrophic states, it has not always been possible to correlate protein accumulation with increased amino acid uti-

Table IV. Effects of Hyperinsulinemia on Kallikrein Levels and In Vivo Incorporation of $\left[{ }^{35} S\right]$ Methionine into Kallikrein and Total Protein in the Kidney

\begin{tabular}{lcc}
\hline & $\begin{array}{l}\text { Control } \\
(n=10)\end{array}$ & $\begin{array}{l}\text { Hyperinsulinemic } \\
(n=14)\end{array}$ \\
\hline $\begin{array}{l}\text { Kallikrein content }(n g / m g \text { protein }) \\
\text { Kallikrein synthesis rate: }\end{array}$ & $41.2 \pm 2.8$ & $49.4 \pm 2.2^{\ddagger}$ \\
$\quad 10^{3} \times$ ratio $(1) /(2)$ & $3.07 \pm 0.23$ & $3.19 \pm 0.18$ \\
1 Kallikrein cpm/mg protein & $25.5 \pm 1.9$ & $35.3 \pm 2.3^{\S}$ \\
2 TCA protein cpm/mg protein & $8,325 \pm 212$ & $11,133 \pm 271^{11}$
\end{tabular}

* Rats were injected with $\left[{ }^{35} S\right]$ methionine (intraperitoneally) and killed after $20 \mathrm{~min}$. The incorporation of methionine label was measured in immunoprecipitated kallikrein (line 1) and total, TCA-precipitated protein (line 2). The ratio of these counts is the relative rate of kallikrein synthesis (see Methods for details). Kallikrein content shown is total immunoreactive kallikrein measured with polyclonal antiserum. See text for active and prokallikrein levels.

${ }^{\ddagger} P<0.05$ vs. control.

${ }^{8} P<0.001$ vs. control.

" $P<0.005$ vs. control. 
lization (27), suggesting that reduced degradation may contribute to the increase in protein content in diabetic kidneys. While we found that the incorporation of $\left[{ }^{35} \mathrm{~S}\right]$ methionine into kallikrein in diabetic kidneys was generally reduced, incorporation into TCA-precipitated protein was not different from control rat kidneys (Table II). Therefore, the reduction in kallikrein synthesis relative to total protein synthesis cannot be explained by increased total protein synthesis. Neither is the reduction in renal kallikrein level in diabetes (nanograms per milligram protein) merely the result of increased protein content, because the changes persist when levels are expressed relative to kidney weight or as total renal kallikrein content. Although the effects of diabetes and insulin on renal kallikrein may not be unique to this enzyme, it is apparent that the spectrum of kallikrein changes we observed are not simply due to generalized changes in renal proteins in response to diabetes or insulin.

In this regard, in the hyperinsulinemic rats we could not attribute the increase in renal active kallikrein to a specific increase in kallikrein synthesis rate. Since the major route of kallikrein elimination from renal tissue is the urine (28), and urinary excretion of prokallikrein in hyperinsulinemic rats was markedly reduced $(46 \%)$, it is reasonable to suggest that the increase in tissue active kallikrein resulted from reduced prokallikrein excretion and increased activation. Although reduced, the magnitude of reduction in prokallikrein excretion in hyperinsulinemic rats was not accompanied by a quantitatively equivalent increase in renal kallikrein content. That is, daily prokallikrein excretion was reduced $\sim 60 \mu \mathrm{g}$, whereas the increase in active and prokallikrein of both kidneys totalled $\sim 5 \mu \mathrm{g}$. This suggests that a significant portion of the unexcreted prokallikrein must be either degraded in the kid- ney or released by other routes as zymogen or active enzyme. We did find a small (18\%), but significant, increase in the level of serum immunoreactive tissue kallikrein in these rats (data not shown). The notion that increased activation of renal tissue prokallikrein occurred in hyperinsulinemic rats is supported by the consistent finding that increasing circulating insulin, from low to normal or normal to excess, was associated with increased renal active kallikrein, independent of changes in tissue prokallikrein level.

The relationships between insulin and renal kallikrein regulation suggested by our data are depicted in Fig. 6. Several facts may be relevant to our finding that insulin stimulates prokallikrein synthesis and activation. Receptors for insulin have been identified on the basolateral membrane of rat and rabbit renal tubule cells $(29,30)$, and in rat kidney these receptors have structural and functional properties similar to insulin receptors in other tissues (29). In the rabbit it has been shown that the density of insulin receptors is greatest in the distal convoluted tubule (30), a site where kallikrein has been localized by immunohistochemical and microdissection techniques (31-33), and where kinins are generated (34). Furthermore, ultrastructural immunocytochemistry has demonstrated that kallikrein is distributed along the basolateral membranes of connecting tubule cells in the distal tubule (35), and these membranes, when isolated, contain both active enzyme and prokallikrein (36). Amongst its effects on renal function, insulin increases sodium reabsorption by the distal tubule (37). It is possible that renal kallikrein could be involved in this action of insulin because states of sodium retention can be associated with raised renal kallikrein levels and synthesis $(18,38)$, and kinin products of tissue kallikreins are potent stimuli to renal epithelial ion transport $(9-11)$. It is

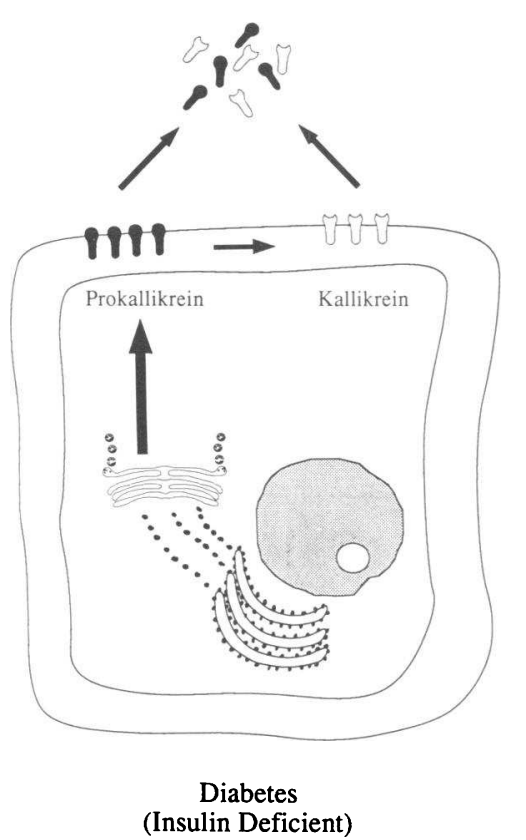

Figure 6. Schematic representation of renal kallikrein during states of deficient, normal, or excess insulin. The arrow within each cell represents the rate of kallikrein synthesis; the arrow within the membrane, the rate of prokallikrein activation, and the arrows above the cells represent the rates of excretion of prokallikrein and active kallikrein. The sizes of the arrows are directly proportional to the rates

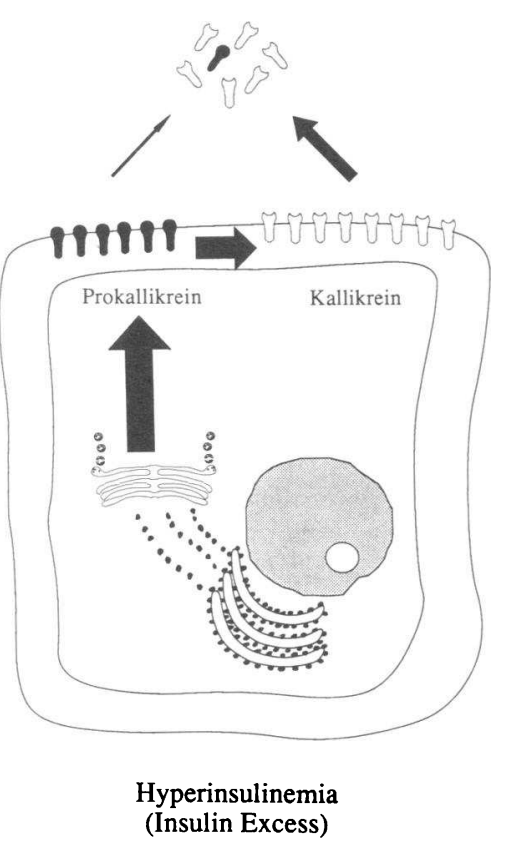

represented. The numbers of pegs, solid (prokallikrein) and shaded (active kallikrein), are proportional to the measured levels of enzyme in tissue (depicted within the membrane) or urine (above each cell). It is not certain that all activation occurs within the membrane, or that all tissue kallikrein is membrane bound. 
worthy of note that when diabetic or normal rats were treated with insulin in our study, increases in renal kallikrein were accompanied by significant reductions in sodium excretion (data not shown).

Other data are beginning to suggest that renal kallikrein and kinins participate in tubuloglomerular feedback mechanisms (1-8), and our preliminary studies support the possibility that the abnormalities of renal kallikrein we have discovered may contribute to abnormalities in renal hemodynamics and glomerular filtration. In the untreated STZ-diabetic rat, reduced renal and urinary active kallikrein are associated with reduced glomerular filtration rate and renal plasma flow, and both the kallikrein and renal function abnormalities are reversed by treatment with insulin (39). Diabetic rats that are chronically treated with insulin show increases above normal in renal as well as urinary active kallikrein. These rats have raised renal plasma flow and glomerular filtration, which can be reversed by treatment with aprotinin (40). The nondiabetic hyperinsulinemic rats that have raised renal active kallikrein also show increased relative rates of glomerular filtration and renal plasma flow (unpublished observations). More recently, we have found that other hyperfiltration states are associated with raised kallikrein activity as well (41). The availability of specific kallikrein inhibitors (42) and kinin antagonists (43) now make it possible to begin to assess the significance of alterations in kallikrein regulation to renal function.

\section{Acknowledgments}

We wish to thank Teresa Pickens and Michael Bigelow for technical support and the assistance of Barbara Whitlock in preparing the manuscript.

This work was supported by the Veterans Administration, by grants from National Institutes of Health (National Institute of Diabetes, Digestive and Kidney Diseases, DK35977, National Heart, Lung, and Blood Institute, HL17705 and HL29397), and by funds for biomedical research from the Medical University of South Carolina. Dr. Jaffa was supported by the College of Graduate Studies, Medical University of South Carolina, during these studies.

\section{References}

1. Levy, S. B., J. J. Lilley, R. P. Frigon, and R. A. Stone. 1977. Urinary kallikrein and plasma renin activity as determinants of renal blood flow. J. Clin. Invest. 60:129-138.

2. Johnston, P. A., D. B. Barnard, N. S. Perrin, L. Arbeit, W. Lieberthal, and N. G. Levinsky. 1981. Control of rat renal vascular resistance during alterations in sodium balance. Circ. Res. 48:728733.

3. Barajas, L., K. Powers, O. Carretero, A. G. Scicli, and T. Inagami. 1986. Immunocytochemical localization of renin and kallikrein in the rat renal cortex. Kidney Int. 29:965-970.

4. Tomita, K., and J. P. Pisano. 1984. Binding of $\left[{ }^{3} \mathrm{H}\right]$-bradykinin in isolated nephron segments of the rabbit. Am. J. Physiol. 246:F732F737.

5. Uglesity, A., J. I. Kreisberg, and L. Levine. 1983. Stimulation of arachidonic acid metabolism in rat kidney mesangial cells by bradykinin, antidiuretic hormone and their analogues. Prostaglandins Leukotrienes Med. 10:83-93.

6. Hura, C. E., and R. T. Kunau. 1986. Prostaglandin production by isolated renal afferent arterioles. Kidney Int. 29:385. (Abstr.)

7. Ichikawa, I., and V. Kon. 1983. Glomerular mesangium as an effector locus for the tubuloglomerular feedback system and renal sympathetic innervation. Fed. Proc. 42:3075-3079.

8. Brenner, B. M., I. Ichikawa, and W. M. Deen. 1981. Glomerular filtration. In The Kidney. B. M. Brenner and F. C. Rector, editors. W. B. Saunders Co., Philadelphia, London, Toronto. 289-327.

9. Tomita, K., J. J. Pisano, and M. A. Knepper. 1985. Control of $\mathrm{Na}^{+}$and $\mathrm{K}^{+}$transport in the cortical collecting duct of the rat. Effects of bradykinin, vasopressin, and deoxycorticosterone. J. Clin. Invest. 76:132-136.

10. Schuster, V. L., J. P. Kokko, and H. R. Jacobson. 1984. Interactions of lysyl-bradykinin and antidiuretic hormone in the rabbit cortical collecting tubule. J. Clin. Invest. 73:1659-1667.

11. Cuthbert, A. W., A. M. George, and L. MacVinish. 1985. Kinin effects on electrogenic ion transport in primary cultures of pig renal papillary collecting tubule cells. Am. J. Physiol. 249:F439-F447.

12. Cuthbert, A. W., and H. S. Margolius. 1982. Kinins stimulate net chloride secretion by the rat colon. Br. J. Pharmacol. 75:587-598.

13. Mayfield, R. K., and H. S. Margolius. 1983. Renal kallikreinkinin system: relation to renal function and blood pressure. Am. J. Nephrol. 3:145-155.

14. Mayfield, R. K., H. S. Margolius, J. H. Levine, H. J. Wohltmann, C. B. Loadholt, and J. A. Colwell. 1984. Urinary kallikrein excretion in insulin-dependent diabetes mellitus and its relationship to glycemic control. J. Clin. Endocrinol. Metab. 59:278-286.

15. Mayfield, R. K., H. S. Margolius, G. S. Bailey, D. H. Miller, D. A. Sens, J. Squires, and D. H. Namm. 1985. Urinary and renal tissue kallikrein in the streptozotocin-diabetic rat. Diabetes. 34:22-28.

16. Hayashi, M., S. Senba, I. Saito, W. Kitajuna, and T. Saruta. 1983. Changes in blood pressure, urinary kallikrein, and urinary prostaglandin $E_{2}$ in rats with streptozotocin-induced diabetes. NaunynSchmiedeberg's Arch. Pharmacol. 322:290-294.

17. Ando, T., J. Chao, L. Chao, and H. S. Margolius. 1986. An improved method for the measurement of rat tissue kallikrein using a monoclonal antibody which recognizes only active kallikrein. $A d v$. Exp. Biol. Med. 198B:515-522.

18. Miller, D. H., J. Chao, and H. S. Margolius. 1984. Tissue kallikrein synthesis and its modification by testosterone or low dietary sodium. Biochem. J. 218:37-43.

19. Kobayashi, M., and J. M. Olefsky. 1978. Effect of experimental hyperinsulinemia on insulin binding and glucose transport in isolated rat adipocytes. Am. J. Physiol. 235:E53-E62.

20. Shimamoto, K., H. S. Margolius, J. Chao, and A. R. Crosswell. 1979. A direct radioimmunoassay of rat urinary kallikrein and comparison with other measures of urinary kallikrein activity. J. Lab. Clin. Med. 94:172-179.

21. Kadish, A. H., R. L. Little, and J. C. Sternberg. 1968. A new and rapid method for the determination of glucose by measurement of rate of oxygen consumption. Clin. Chem. 14:116-131.

22. Lowry, O. H., N. J. Rosebrough, A. L. Farr, and R. J. Randall. 1951. Protein measurement with the folin phenol reagent. J. Biol. Chem. 193:265-275.

23. Morgan, C. R., and A. Lazarow. 1953. Immunoassay of insulin: two antibody system. Diabetes. 12:115-126.

24. Tanaka, S., J. Chao, and H. S. Margolius. 1982. A direct radioimmunoassay for immunoreactive glandular kallikrein in rat serum. Fed. Proc. 41:1473. (Abstr.)

25. Iynedjian, P. B., F. J. Ballard, and R. W. Hanson. 1975. The regulation of phosphoenolpyruvate carboxykinase (GTP) synthesis in rat kidney cortex. J. Biol. Chem. 250:5596-5603.

26. Seyer-Hansen, K. 1976. Renal hypertrophy in streptozotocindiabetic rats. Clin. Sci. Mol. Med. 51:551-555.

27. Coe, F. L., and P. R. Korty. 1967. Protein synthesis during compensatory renal hypertrophy. Am. J. Physiol. 213:1585-1589.

28. Mills, I. H., C. L. Patterson, and P. E. Ward. 1975. The role of the kidney in the inactivation of injected kallikrein. J. Physiol. (Lond.). 251:281-286.

29. Rabkin, R., P. Hirayama, R. A. Roth, and B. H. Frank. 1986. Effect of experimental diabetes on insulin binding by renal basolateral membranes. Kidney Int. 30:348-354.

30. Nakamura, R., D. S. Emmanouel, and A. I. Katz. 1983. Insulin 
binding sites in various segments of the rabbit nephron. J. Clin. Invest. 72:388-392.

31. Simson, J. A., S. Spicer, J. Chao, L. Grimm, and H. S. Margolius. 1979. Kallikrein localization in rodent salivary glands and kidney with the immunoglobulin-enzyme bridge technique. J. Histochem. Cytochem. 27:1567-1576.

32. Omata, K., O. A. Carretero, A. G. Scicli, and B. A. Jackson. 1982. Localization of active and inactive kallikrein (kininogenase activity) in the microdissected rabbit nephron. Kidney Int. 22:602-607.

33. Marchetti, J., M. Imbert-Teboul, F. Alhenc-Gelas, J. Allergrini, J. Menard, and F. Morel. 1984. Kallikrein along the rabbit microdissected nephron: a micro method for its measurement. Pfluegers Arch. Eur. J. Physiol. 401:27-33.

34. Scicli, A. G., O. A. Carretero, A. Hampton, P. Cortes, and N. B. Oza. 1976. Site of kininogenase secretion in the dog nephron. Am. J. Physiol. 230:533-536.

35. Figueroa, C. D., I. Caorsi, J. Subiabre, and C. P. Vio. 1984. Immunoreactive kallikrein localization in the rat kidney. $J$. Histochem. Cytochem. 32:117-121.

36. Yamada, K., and E. G. Erdos. 1982. Kallikrein and prokallikrein of the isolated basolateral membrane of rat kidney. Kidney Int. 22:331-337.
37. DeFronzo, R. A., C. R. Cook, R. Andres, G. R. Falvona, and P. J. Davis. 1975. The effect of insulin on renal handling of sodium, potassium, calcium, and phosphate in man. J. Clin. Invest. 55:845855.

38. Margolius, H. S., D. Horwitz, J. J. Pisano, and H. R. Keiser. 1974. Urinary kallikrein in hypertension: relationships to sodium intake and sodium-retaining steroids. Circ. Res. 35:820-825.

39. Harvey, J. N., A. A. Jaffa, H. S. Margolius, and R. K. Mayfield. 1986. Renal kallikrein and the hemodynamic abnormalities of the diabetic kidney. Clin. Res. 34:204A. (Abstr.)

40. Harvey, J. N., A. A. Jaffa, H. S. Margolius, and R. K. Mayfield. 1987. Relation of renal kallikrein to the glomerular hyperfiltration of experimental diabetes. Diabetes. 36:85A. (Abstr.)

41. Jaffa, A. A., J. N. Harvey, H. S. Margolius, and R. K. Mayfield. 1986. A potential role of renal kallikrein as a mediator of dietary protein effects on renal function. Clin. Res. 34:599A. (Abstr.)

42. Okunishi, H., J. Spragg, and J. Burton. 1986. The design of substrate analogue tissue kallikrein inhibitors. Hypertension. 8(Suppl. I): $114-118$

43. Vavrek, R. J., and J. M. Stewart. 1985. Competitive antagonists of bradykinin. Peptides. 6:161-164. 